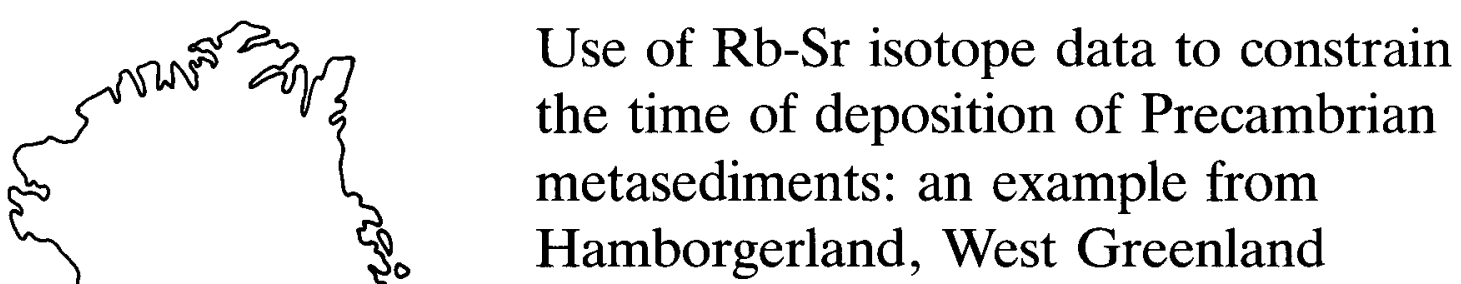

Feiko Kalsbeek

\begin{abstract}
In high-grade metamorphic terrains it is often not possible to determine the relative age of metasedimentary units by field investigation. However, the time of deposition of the original sediment can be constrained by consideration of the Sr-isotopic evolution of the rocks on the scale of an outcrop. An outline of the method is given, and Rb-Sr data for high-grade (granulite facies) metasediments from Hamborgerland, West Greenland, are discussed as an example. Sm-Nd model age data indicate that these rocks were derived by erosion of a 3000-3200 Ma basement. Deposition took place not long before $2700 \mathrm{Ma}$ ago, and closure of the $\mathrm{Rb}$-Sr isotope system after high-grade metamorphism occurred at about $2600 \mathrm{Ma}$.
\end{abstract}

F. K., Geological Survey of Greenland, Øster Voldgade 10, DK-1350 Copenhagen K, Denmark.

The only way in which the age of deformed, unfossiliferous, Precambrian sediments can be determined is by isotopic investigation, especially by using $\mathrm{Rb}-\mathrm{Sr}$, $\mathrm{Sm}-\mathrm{Nd}$ and $\mathrm{Pb}-\mathrm{Pb}$ data. This is, however, not straightforward. The history of metasediments involves at least three stages which influence their $\mathrm{Sr}, \mathrm{Nd}$ and $\mathrm{Pb}$-isotopic composition: (i) formation of the pre-erosion source rocks of the sediments; (ii) formation of the sediment (weathering, erosion, deposition, diagenesis); (iii) metamorphism which may disturb earlier established isotope systematics.

$\mathrm{Sm}-\mathrm{Nd}$ analysis yields evidence on the age of the source region of the sediment. Erosion, sediment formation and later metamorphism commonly have little influence on $\mathrm{Sm} / \mathrm{Nd}$ ratios, and hence do not significantly disturb the $\mathrm{Nd}$-isotopic evolution of the rock (e.g. McCulloch \& Wasserburg, 1978). $\mathrm{Pb}-\mathrm{Pb}$ isochrons have been used with success to date the time of deposition and diagenesis of Precambrian limestones (Moorbath et al., 1987). U-Pb isotope systems are, however, strongly affected by later metamorphism, and $\mathrm{Pb}-\mathrm{Pb}$ isochrons on marbles date the time of metamorphism rather than the time of deposition (e.g. Taylor \& Kalsbeek, 1990).

$\mathrm{Rb}-\mathrm{Sr}$ data for unmetamorphosed sediments are often difficult to interpret because isotopic equilibration between clastic grains and diagenetic minerals is not normally achieved. However, Rb-Sr data on diagenetic minerals have been used to date the time of diagenesis (see e.g. Clauer, 1982). Rb-Sr whole rock isochron dates of high-grade metapelitic sediments yield information on the time of metamorphism, but give no indication of the time of deposition of the original sediment. This is because $\mathrm{Sr}$ is mobile during metamorphism, especially in rocks which are rich in volatiles, so that partial Sr-isotopic equilibration is common. Strictly speaking, such isochrons date the time after metamorphism when the rocks have cooled sufficiently to halt further diffusion of $\mathrm{Rb}$ and $\mathrm{Sr}$, rather than the peak of metamorphism. However, this distinction is not always relevant because $\mathrm{Sr}$-isotopic equilibration is normally far from complete, so that the isochron ages often have large error margins.

$\mathrm{Rb}-\mathrm{Sr}$ isotope data may also be used to constrain the time of sediment deposition, by consideration of the $\mathrm{Sr}$-isotopic evolution of the rocks with time. Although this method has commonly been used for igneous rocks and their metamorphic equivalents (e.g. Moorbath, 1975), it has rarely been applied to sedimentary rocks. The method is briefly discussed, and its application to high-grade metasediments from Hamborgerland, north of Maniitsoq (Sukkertoppen) in West Greenland (Fig. 1) is described below. 


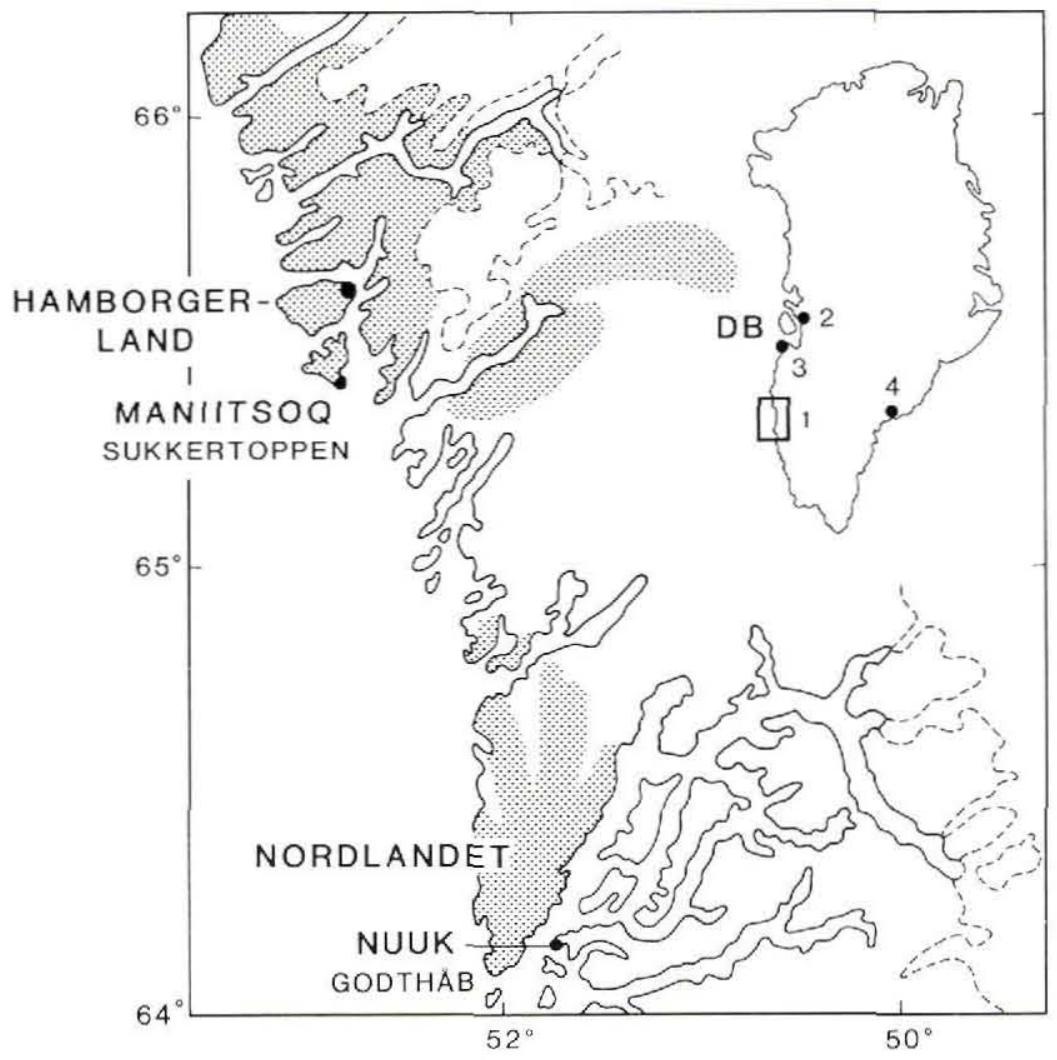

Fig. 1. Sketch map of part of West Greenland with main areas of granulitefacies metamorphism stippled. The locality on Hamborgerland where the analysed supracrustal rocks were collected is indicated. The inset map of Greenland shows the location of the sketch map (1) and the localities of other supracrustal rocks discussed in the text: (2) Qeqertakavsak and Qapiarfit in north-eastern Disko Bugt. (3) Ikamiut and (4) in the Ammassalik Mobile Belt of southern East Greenland.

\section{Use of $\mathrm{Rb}-\mathrm{Sr}$ isotope data to constrain the time of deposition of (meta)sediments}

An estimate of the time of deposition of (meta)sediments may be obtained by extrapolation of the ${ }^{87} \mathrm{Sr} /{ }^{86} \mathrm{Sr}$ ratios of the rocks backward in time from the present value, with the help of the measured ${ }^{87} \mathrm{Rb} /{ }^{88} \mathrm{Sr}$ values, using the basic equation of Sr-isotopic evolution:

$$
\left({ }^{87} \mathrm{Sr} /{ }^{86} \mathrm{Sr}\right)_{t=0}=\left({ }^{87} \mathrm{Sr} /{ }^{86} \mathrm{Sr}\right)_{t}+{ }^{87} \mathrm{Rb} /{ }^{86} \mathrm{Sr}\left(e^{j . t}-1\right)
$$

where $\lambda$ is the decay constant for ${ }^{87} \mathrm{Rb}\left(1.42 \times 10^{-11} \mathrm{a}^{-1}\right)$, and $t$ is time. Time is measured backward, i.e. $t=0$ is today (cf. Fig. 2B). The ${ }^{x 7} \mathrm{Sr} /{ }^{86} \mathrm{Sr}$ ratio of the sediments at their time of deposition $\left({ }^{87} \mathrm{Sr} /{ }^{\beta / 6} \mathrm{Sr}\right)$, is only rarely known. However, it can be safely assumed that it cannot have been lower than 0.701 , because few crustal rocks ever had such low $\mathrm{Sr}$-isotope ratios (see e.g. Faure, 1986). By back-extrapolating the $\mathrm{Sr}$-isotope ratios to the time at which the samples had ${ }^{87} \mathrm{Sr}{ }^{80} \mathrm{Sr}=$ 0.701 . one obtains the maximum possible time the rocks can have existed with their present ${ }^{87} \mathrm{Rb} /{ }^{86} \mathrm{Sr}$ ratios. $\mathrm{Be}$ cause high $\mathrm{Rb} / \mathrm{Sr}$ ratios of pelitic sediments are a depositional characteristic, this can be regarded as the maximum time elapsed since deposition. This is because the processes of erosion, sediment fractionation and deposition result in a significant increase in $\mathrm{Rb} / \mathrm{Sr}$ ratios in pelitic sediments compared to their source rocks. Because of their high proportion of clay minerals, pelitic sediments nearly always have much higher $\mathrm{K}$ and $\mathrm{Rb}$, and lower $\mathrm{Ca}$ and $\mathrm{Sr}$ contents, than their igneous precursors, and thus much higher $\mathrm{Rb} / \mathrm{Sr}$ ratios.

Maximum deposition ages estimated in this way are dependent on three assumptions: (1) Sr-isotopic equilibration during metamorphism has taken place on a local scale only; larger rock volumes retain their isotopic identity; (2) measured ${ }^{87} \mathrm{Sr} /{ }^{86} \mathrm{Sr}$ and ${ }^{87} \mathrm{Rb} /{ }^{86} \mathrm{Sr}$ ratios are representative of such a larger volume of rock; (3) ${ }^{87} \mathrm{Rb} /{ }^{86} \mathrm{Sr}$ ratios of the rock as a whole have not significantly increased since deposition. The validity of assumptions (1) and (2), as a first approximation, is supported by several studies which have shown that, during metamorphism. rock volumes of the size of a locality have often retained their isotopic identity, whereas individual samples have not (e.g. Zartman \& Stern, 1967 Köhler \& Müller-Sohnius, 1980). In such cases mean values of ${ }^{87} \mathrm{Rb} /{ }^{866} \mathrm{Sr}$ and ${ }^{87} \mathrm{Sr} /{ }^{86} \mathrm{Sr}$ for a number of samples from the same locality can be used to determine the age of the rock better than single samples, because local gains and losses of ${ }^{87} \mathrm{Sr}$ largely cancel out. Using very 

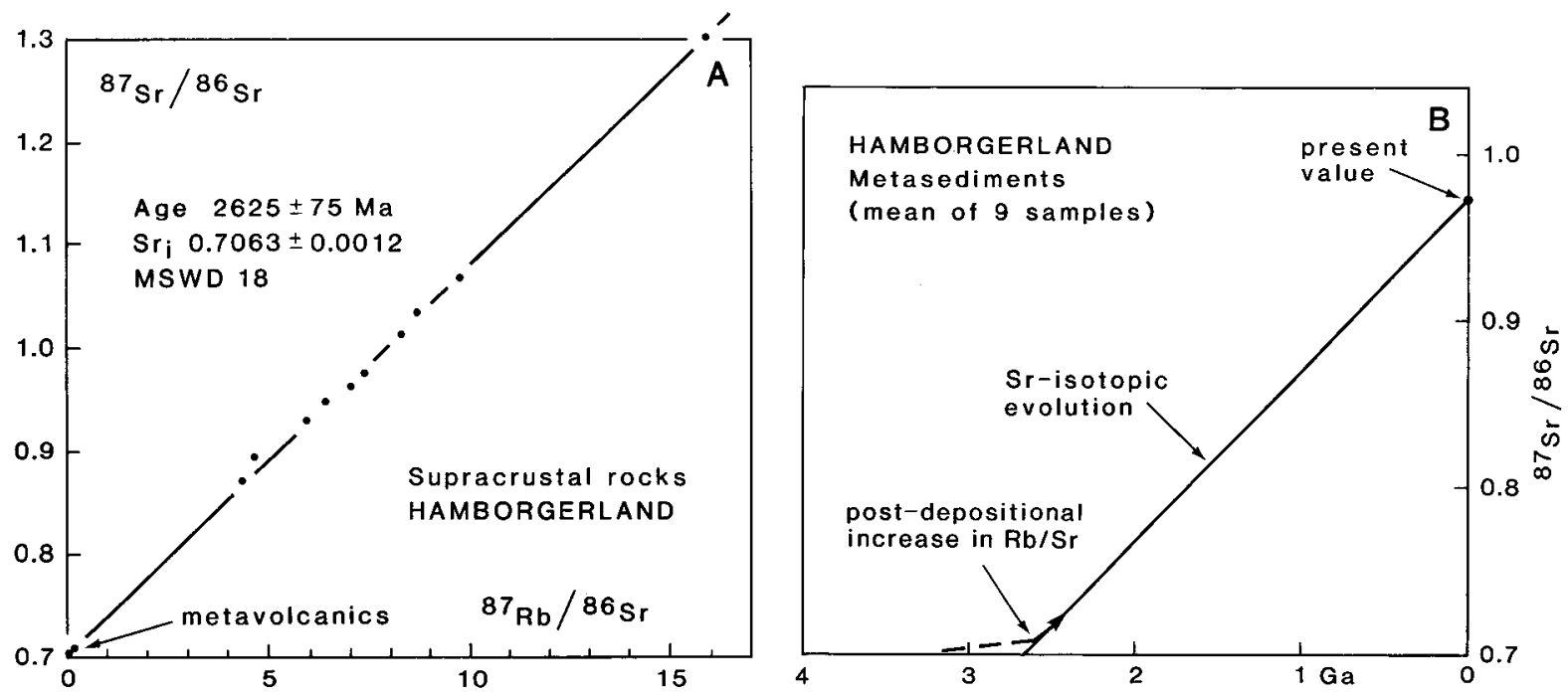

Fig. 2A. Rb-Sr isochron diagram for supracrustal rocks from Hamborgerland, West Greenland. The two samples with low ${ }^{87} \mathrm{Sr}{ }^{86} \mathrm{Sr}$ ratios are metavolcanic rocks; the others are metasediments. Fig. 2B shows the extrapolation backward in time of the mean ${ }^{87} \mathrm{Sr} /{ }^{86} \mathrm{Sr}$ value for nine of the metasediment samples calculated from the mean ${ }^{87} \mathrm{Rb} /{ }^{86} \mathrm{Sr}$ ratio, and demonstrates that the rocks cannot have been deposited long before $c$. $2700 \mathrm{Ma}$, see text. The broken line shows that, if the sediments were deposited before $3000 \mathrm{Ma}$ ago, a very substantial increase in $\mathrm{Rb} / \mathrm{Sr}$ ratios must have taken place during metamorphism. This is regarded as unlikely.

large single samples has the same effect. Assumption (3) is probably valid in many cases. High-grade metamorphism may lead to depletion in $\mathrm{Rb}$ and consequent lowering of $\mathrm{Rb} / \mathrm{Sr}$ ratios, whereas increase in $\mathrm{Rb} / \mathrm{Sr}$ is not normally observed. However, although the various assumptions mentioned above appear to be reasonably well fulfilled in most cases, the applicability of this approach must be tested on specific sample suites in order to test whether or not it yields results that fit in with other information on the relevant area. Furthermore, since assumptions (1) and (2) are approximations only, no great precision of the age estimates can be expected.

\section{Metasediments from Hamborgerland, West Greenland}

Minor occurrences of metasedimentary rocks are present in the high-grade metamorphic terrain in the northern part of the Archaean craton of West Greenland, north of Maniitsoq/Sukkertoppen (Fig. 1). They commonly contain sheets of garnetiferous granite, formed by local anatexis of the sediments. Metasediments are commonly deeply weathered, and fresh material is not easily obtained. For this study 12 samples were collected from a locality at $65^{\circ} 37.2^{\prime} \mathrm{N} ; 52^{\circ} 55.5^{\prime} \mathrm{W}$ on Hamborgerland, from fresh blocks in a scree underneath a steep wall with outcrops of supracrustal rocks. Ten of these are metasediments: biotite-rich paragneisses with abun- dant garnet, cordierite and sillimanite. Alumina runs up to 25 weight $\%$ in some samples (Table 1 ), with $50-55 \%$ $\mathrm{SiO}_{2}$. Other samples are more silicic $\left(\mathrm{SiO}_{2}\right.$ up to c. $\left.80 \%\right)$ and less aluminous $\left(\mathrm{Al}_{2} \mathrm{O}_{3}\right.$ c. $\left.12 \%\right)$. This variation is probably related to the nature of the original sediments: pelitic for the aluminous samples and psammitic for the siliceous ones. $\mathrm{Rb}$ concentrations vary with $\mathrm{Al}$ and $\mathrm{Si}$ : up to $c .150 \mathrm{ppm}$ in the metapelites and $c .40 \mathrm{ppm}$ in metapsammitic samples (Table 1).

Two samples probably represent basic metavolcanic rocks. They consist mainly of plagioclase, hypersthene and diopside, with minor proportions of biotite, hornblende and opaque minerals. One sample (263429, Table 1) contains c. $10 \%$ of quartz. These rocks have only a few ppm Rb (Table 1).

$\mathrm{Rb}$-Sr isotope data (Table 1) for all 12 samples yield a poorly fitted isochron corresponding to an age of 2625 $\pm 75 \mathrm{Ma}, \mathrm{Sr}_{\mathrm{j}} 0.7063 \pm 0.0012$, MSWD 18 (Fig. 2A). An isochron calculation involving the 10 metasediments alone gives a slightly younger age and a higher $\mathrm{Sr}_{i}$ value $(2500 \pm 200 \mathrm{Ma}, 0.719 \pm 0.018)$, but only slightly lower MSWD (15). Precise interpretation of these data is not possible, but it is evident that the $\mathrm{Rb}-\mathrm{Sr}$ isotope systems did not close until very late in the Archaean.

Figure 2B shows the backward extrapolation to a value of 0.701 of the mean ${ }^{87} \mathrm{Sr} /{ }^{86} \mathrm{Sr}$ ratio for nine of the samples (omitting the two low $\mathrm{Rb} / \mathrm{Sr}$ metavolcanic rocks and the sample with highest $\mathrm{Rb} / \mathrm{Sr}$, which does not seem to be representative of the main suite of metasedi- 
Table 1. Chemical, Rb-Sr and Sm-Nd isotope data for metasediments from Hamborgerland, West Greenland

A: Chemical and $\mathrm{Rb}-\mathrm{Sr}$ data

\begin{tabular}{lcccccc}
\hline $\begin{array}{c}\text { Sample } \\
\text { no }\end{array}$ & $\begin{array}{c}\mathrm{SiO}_{2} \\
(\mathrm{wt} \%)\end{array}$ & $\begin{array}{c}\mathrm{Al}_{2} \mathrm{O}_{3} \\
(\mathrm{wt} \%)\end{array}$ & $\begin{array}{c}\mathrm{Rb} \\
(\mathrm{ppm})\end{array}$ & $\begin{array}{c}\mathrm{Sr} \\
(\mathrm{ppm})\end{array}$ & ${ }^{87} \mathrm{Rb} /{ }^{86} \mathrm{Sr}$ & ${ }^{87} \mathrm{Sr} /{ }^{86} \mathrm{Sr}$ \\
\hline 263421 & 53.64 & 25.83 & 90 & 43 & 6.41 & 0.9513 \\
263422 & 79.39 & 11.62 & 37 & 19 & 5.92 & 0.9321 \\
263423 & 59.80 & 17.92 & 59 & 25 & 7.09 & 0.9630 \\
$263424^{*}$ & 46.25 & 19.78 & 2.6 & 76 & 0.076 & 0.7100 \\
263425 & 53.34 & 22.96 & 147 & 60 & 7.39 & 0.9776 \\
263426 & 79.55 & 11.92 & 37 & 24 & 4.55 & 0.8964 \\
263427 & 49.45 & 23.28 & 118 & 42 & 8.29 & 1.0161 \\
263428 & 51.53 & 24.79 & 155 & 30 & 15.87 & 1.3027 \\
$263429 *$ & 54.18 & 17.51 & 1.3 & 108 & 0.027 & 0.7065 \\
263430 & 48.45 & 24.40 & 101 & 36 & 8.64 & 1.0382 \\
263431 & 56.04 & 24.31 & 98 & 30 & 9.73 & 1.0673 \\
263432 & 58.31 & 18.47 & 69 & 46 & 4.40 & 0.8724 \\
\hline
\end{tabular}

*metavolcanic rocks

B: Sm-Nd data

\begin{tabular}{cccccc}
\hline $\begin{array}{c}\text { Sample } \\
\text { no }\end{array}$ & $\begin{array}{c}\mathrm{Sm} \\
(\mathrm{ppm})\end{array}$ & $\begin{array}{c}\mathrm{Nd} \\
(\mathrm{ppm})\end{array}$ & ${ }^{147} \mathrm{Sm} /{ }^{144} \mathrm{Nd}$ & ${ }^{143} \mathrm{Nd} /{ }^{144} \mathrm{Nd}$ & $\begin{array}{c}\mathrm{T}_{\mathrm{DM}} \\
(\mathrm{Ga})\end{array}$ \\
\hline 263421 & 3.972 & 19.554 & 0.1228 & 0.511136 & 3220 \\
263422 & 1.360 & 7.497 & 0.1096 & 0.510968 & 3050 \\
\hline
\end{tabular}

$\mathrm{SiO}_{2}$ and $\mathrm{Al}_{2} \mathrm{O}_{3}$ by XRF on glass discs (GGU), $\mathrm{Rb}$ and $\mathrm{Sr}$ by XRF on powder tablets. $\mathrm{Rb}, \mathrm{Sr}$ and ${ }^{87} \mathrm{Sr} /{ }^{86} \mathrm{Sr}$ were determined at the Department of Geology, University of Copenhagen. Precisions are as follows: $\mathrm{Rb}$ and $\mathrm{Sr}$ (calibrated against U.S.G.S. rock standards) \pm c. $2 \%,{ }^{87} \mathrm{Rb} /{ }^{86} \mathrm{Sr} \pm$ c. $1 \%$, and ${ }^{87} \mathrm{Sr} /{ }^{86} \mathrm{Sr}$ (normalised and relative to the Eimer and Amend standard $=0.7080) \pm c .0 .00015$ (1 sigma values). Sm-Nd data were acquired at the Age and Isotope Laboratory, Department of Earth Sciences, University of Oxford. Analytical uncertainties are estimated as $c .0 .1 \%$ for $\mathrm{Sm}$ and $\mathrm{Nd}$ concentrations, $0.2 \%$ for ${ }^{147} \mathrm{Sm} /{ }^{144} \mathrm{Nd}$, and 0.000015 for ${ }^{143} \mathrm{Nd} /{ }^{144} \mathrm{Nd}$ (1 sigma). $T_{D M}$ values are crustal residence model ages calculated according to the depleted mantle model of DePaolo (1981).

ments), using the mean ${ }^{87} \mathrm{Rb} /{ }^{86} \mathrm{Sr}$ ratio of these samples. From Fig. 2B it appears that deposition of the sediments from which these paragneisses were formed cannot have taken place long before c. $2700 \mathrm{Ma}$.

Two metasediments were analysed for Sm-Nd (Table 1B). Model ages $\left(T_{D M}\right)$ calculated according to the depleted mantle model of DePaolo (1981) slightly exceed $3000 \mathrm{Ma}$. This indicates that the Hamborgerland sediments were derived by erosion of source rocks which, on average, had an age of about 3000-3200 Ma. The $\mathrm{Rb}$-Sr data suggest that deposition was not much earlier than $2700 \mathrm{Ma}$ ago, and the isochron age of $c$.
2600 Ma probably refers to the time of cooling after high-grade metamorphism.

\section{Discussion}

\section{(a) The Hamborgerland metasediments}

The conclusion that the Hamborgerland sediments cannot have been deposited long before c. $2700 \mathrm{Ma}$ ago is interesting because it disagrees with published isotopic information for this part of Greenland. Parts of the Archaean terrain north of Nuuk/Godthåb are in granulite facies (Fig. 1), and Taylor et al. (1980) have obtained a $\mathrm{Pb}-\mathrm{Pb}$ isochron date of $c .3000 \mathrm{Ma}$ on granulite samples from Nordlandet and from the Maniitsoq/ Sukkertoppen area. This was considered as dating the time of granulite facies metamorphism in both areas. If it was this $3000 \mathrm{Ma}$ granulite facies event that affected the Hamborgerland sediments, then the estimated time of deposition of c. $2700 \mathrm{Ma}$ would be seriously in error. However, new isotope data referred to below show that this is not necessarily the case.

Recent SHRIMP (sensitive high-resolution ion microprobe) U-Pb data on zircons from granulite facies rocks in Nordlandet (Friend \& Nutman in review) have confirmed the $3000 \mathrm{Ma}$ age of granulite facies metamorphism suggested by Taylor et al. (1980). However, zircons from a granite intruding metasediments in the area north of Maniitsoq/Sukkertoppen showed that the rocks there were affected by granulite facies metamorphism c. 2740 Ma ago (Friend \& Nutman in review). The age of emplacement of the granite could not be established with certainty. In the light of these results it would appear plausible that the investigated metasediments were deposited shortly before the 2740 Ma metamorphic event. Considering its lack of precision, the estimated age of deposition from Rb-Sr data, not long before $2700 \mathrm{Ma}$, does not conflict with this suggestion.

It is not known at this time whether other rocks in the Maniitsoq/Sukkertoppen area underwent granulite facies metamorphism both at 3000 and at $2740 \mathrm{Ma}$, or only at $2740 \mathrm{Ma}$, because hardly any isotope data are as yet available. However, it appears that the northern part of the Archaean craton was affected by an orogenic event about 2800-2600 Ma ago during which the sediments were formed and high-grade metamorphism took place. This event has not been identified elsewhere in West Greenland (Friend \& Nutman, in review).

\section{(b) Metasediments from other areas in Greenland}

The method described above for the metasediments from Hamborgerland has also been employed for other metasedimentary sequences in Greenland (Fig. 3), 


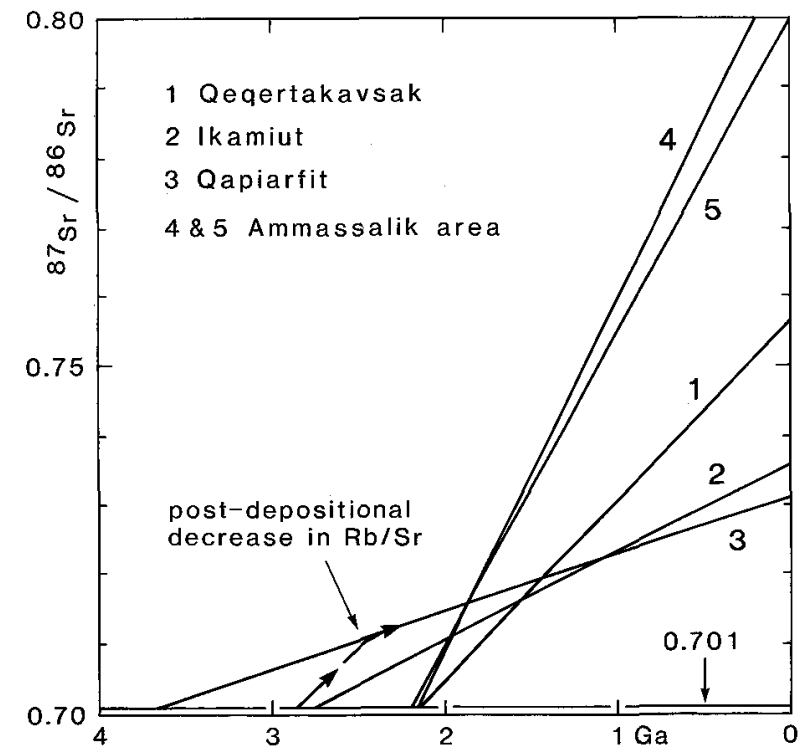

Fig. 3. Evolution of Sr-isotopic compositions for metasediments from various localities in Greenland. Backward extrapolation of mean ${ }^{87} \mathrm{Sr} /{ }^{86} \mathrm{Sr}$ ratios to a value of 0.701 yields an estimate of the maximum age of deposition of the sediments. Metasediments from Qapiarfit (3) may have been deposited as early as $3600 \mathrm{Ma}$ ago. Later deposition, combined with a post-depositional decrease in $\mathrm{Rb} / \mathrm{Sr}$ ratios, however, may result in the same present-day ${ }^{87} \mathrm{Sr} /{ }^{86} \mathrm{Sr}$ ratio (broken line with arrow heads).

where the metasediments in question could either be Archaean or Proterozoic in age. In areas where Archaean rocks have been reworked in early Proterozoic orogenic events this may be very difficult to verify by field evidence. A few examples are given below:

(1) An early Proterozoic age (c. $2100 \mathrm{Ma}$ ) was suggested for low-grade metamorphic sediments from the island Qeqertakavsak in north-eastern Disko Bugt (Kalsbeek et al., 1988; Fig. 1, inset). This result (1, Fig. 3) was later confirmed by field observations. These sediments unconformably overlie an Archaean basement (GGU, unpublished data).

(2) Amphibolite facies paragneisses occur within the basement that underlies the low-grade sediments mentioned above. Samples of these paragneisses have been studied from two localities (Ikamiut, south of Disko Bugt and Qapiarfit in north-eastern Disko Bugt, Fig. 1). $\mathrm{Rb}-\mathrm{Sr}$ isotope systematics for these rocks (GGU, unpublished data) suggest Archaean ages ( 2 and 3, Fig. 3). For Qapiarfit (3 in Fig. 3) a maximum depositional age of c. $3600 \mathrm{Ma}$ is obtained. This does not necessarily indicate an early Archaean age of deposition because a significant decrease in the mean $\mathrm{Rb} / \mathrm{Sr}$ ratio during metamorphism may have occurred, and this would re- sult in a backward extrapolation of the mean ${ }^{87} \mathrm{Sr} /{ }^{86} \mathrm{Sr}$ ratio to 0.701 at an earlier time than the true time of deposition (see Fig. 3).

(3) High-grade metasediments have also been studied from two localities in the early Proterozoic 'Ammassalik Mobile Belt' in South-East Greenland (Fig. 1). For these rocks an early Proterozoic age of deposition (c. $2100 \mathrm{Ma}$ ) is indicated by Rb-Sr data (4 and 5, Fig. 3; Kalsbeek et al., in press). In this case there is no field evidence to support or negate the suggested age of deposition obtained from the Rb-Sr systematics.

To summarise, in several of the cases described above an estimate of the time of deposition of Precambrian metasediments estimated from the $\mathrm{Rb}$-Sr data finds support in field evidence. In other cases there is no supporting evidence, but neither is there any reason to doubt the reliability of the estimate. For the Hamborgerland metasediments there is a major discrepancy between the maximum age of deposition estimated from the $\mathrm{Rb}-\mathrm{Sr}$ data (c. $2700 \mathrm{Ma}$, this paper) and earlier published isotope data on the age of regional metamorphism (c. $3000 \mathrm{Ma}$, Taylor et al., 1980). However, new data reveal that the high-grade metamorphism affecting the Hamborgerland sediments in fact took place much later (c. $2740 \mathrm{Ma}$ ago, Friend \& Nutman in review), making an age of deposition not long before 2700 $\mathrm{Ma}$ entirely plausible. It is concluded that estimates of the time of deposition of metasediments from $\mathrm{Rb}-\mathrm{Sr}$ isotope data are a reliable and useful tool in the study of Precambrian basement terrains.

Acknowledgements. Field work was carried out together with Adam Garde (GGU). The laboratories for X-ray fluorescence spectrometry and isotope geology at the Geological Institute, University of Copenhagen, where the $\mathrm{Rb}-\mathrm{Sr}$ analyses were carried out, are supported by the Danish Natural Science Research Council. Sm-Nd data were acquired at the Age and Isotope Laboratory, Department of Earth Sciences, University of Oxford. I thank Professor S. Moorbath and Dr. P. N. Taylor for access to these facilities and help with the analyses, Stephen Moorbath and several colleagues at GGU for reviews of the manuscript, and Grethe Fuglsang Hansen for drawing the figures.

\section{References}

Clauer, N. 1982: The Rb-Sr method applied to sediments: Certitudes and uncertainties. In Odin, G. S. (ed.) Numerical dating in stratigraphy, 245-276. John Wiley, Chichester, U.K.

DePaolo, D. J. 1981: Neodymium isotopes in the Colorado Front range and crust-mantle evolution in the Proterozoic. Nature (London) 291, 193-196. 
Faure, G. 1986: Principles of isotope geology (2nd ed.), 589 pp. John Wiley and Sons, New York.

Friend, C. R. L. \& Nutman, A. P. in review: Two Archaean granulite facies metamorphic events in the Nuuk-Maniitsoq region, West Greenland: correlation with the Sagleq block, Labrador. Manuscript submitted to Can. J. Earth Sci.

Kalsbeek, F., Taylor, P. N. \& Pidgeon, R. T. 1988: Unreworked Archaean basement and Proterozoic supracrustal rocks from northeastern Disko Bugt: implications for the nature of Proterozoic mobile belts in Greenland. Can. J. Earth Sci. 25, 773-782.

Kalsbeek, F., Austrheim, H., Bridgwater, D., Hansen, B. T., Pedersen, S. \& Taylor, P. N. in press: Geochronology of Archaean and Proterozoic events in the Ammassalik area, South-East Greenland, and comparisons with the Lewisian of Scotland and the Nagssugtoqidian of West Greenland. Precambrian Res.

Köhler, H. \& Müller-Sohnius, D. 1980: Rb-Sr systematics on paragneiss series from the Bavarian Moldanubicum, Germany. Contrib. Mineral. Petrol. 71, 387-392.

McCulloch M. T. \& Wasserburg, G. J. 1978: Sm-Nd and Rb-Sr chronology of continental crust formation. Science 200, 1003-1011.

Moorbath, S. 1975: Evolution of Precambrian crust from strontium isotopic evidence. Nature 254, 395-397.

Moorbath, S., Taylor, P. N., Orpen, J. L., Treloar, P. \& Wilson, J. F. 1987: First radiometric dating of Archaean stromatolitic limestone. Nature (London) 326, 865-867.

Taylor, P. N. \& Kalsbeek, F. 1990: Dating the metamorphism of Precambrian marbles: Examples from Proterozoic mobile belts in Greenland. Chem. Geol. (Isot. Geosci. Sect.) 86, 21-28.

Taylor, P. N., Moorbath, S., Goodwin, R. \& Petrykowski, A. C.1980: Crustal contamination as an indicator of the extent of early Archaean crust: $\mathbf{P b}$ isotopic evidence from the late Archaean gneisses of West Greenland. Geochim. Cosmochim. Acta 44, 1437-1453.

Zartman, R. E. \& Stern, T. W. 1967: Isotopic age and geologic relationships of the Little Elk granite, North Black Hills, South Dakota. U.S. Geol. Surv. Prof. Pap. 575-D, D157D163. 